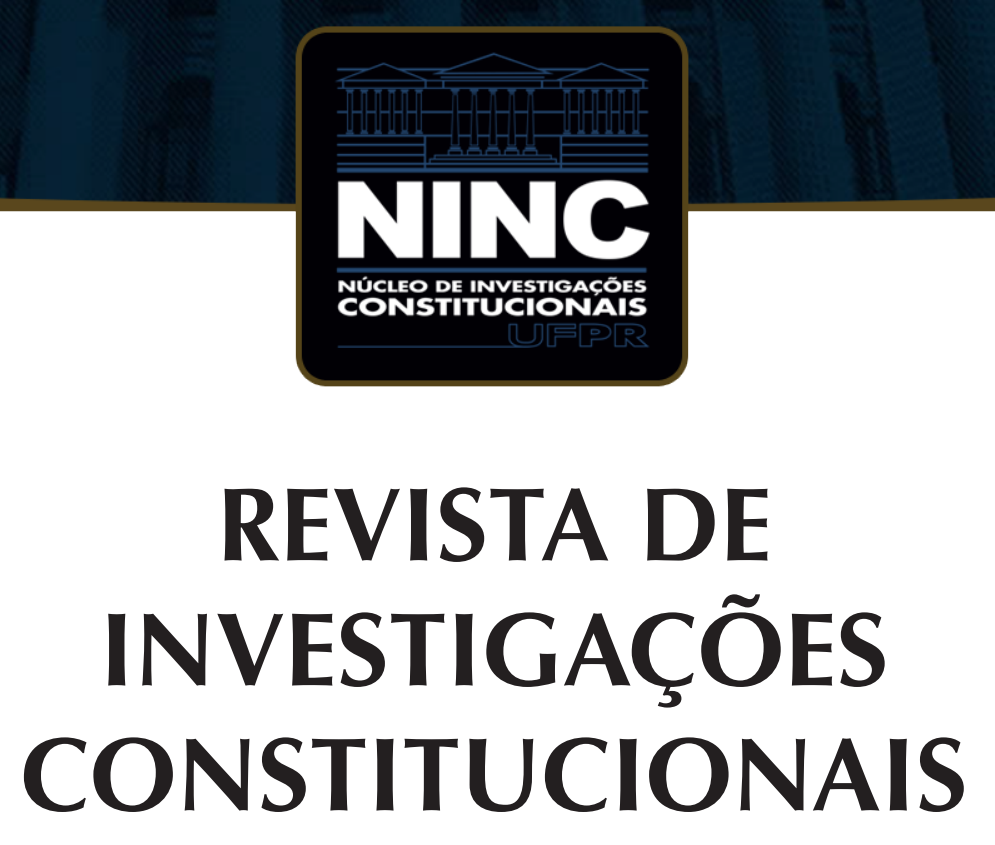

JOURNAL OF CONSTITUTIONAL RESEARCH

vol. 6 | n. 1 | janeiro/abril 2019 | ISSN 2359-5639 | Periodicidade quadrimestral Curitiba | Núcleo de Investigações Constitucionais da UFPR | www.ninc.com.br 


\title{
Brazil in comparative perspective: the legacy of the founding, and the future of constitutional development ${ }^{*}$ \\ O Brasil em perspectiva comparada: o legado da fundação e o futuro do desenvolvimento constitucional
}

\author{
ANA BEATRIZ VANZOFF ROBALINHO CAVALCANTII, ** \\ ${ }^{\mathrm{I}}$ Yale Law School (United States of America) \\ anabeatrizrobalinho@gmail.com \\ Recebido/Received: 30.04.2018 / April 30 $0^{\text {th }}, 2018$ \\ Aprovado/Approved: 30.04.2019 / April 30th', 2019
}

Abstract

This paper analyzes the Brazilian constitutional founding in a comparative perspective, endeavoring to understand how the founding's identity influenced constitutional development through the three decades since the constitutional document was enacted. By creating a link between the constitutional founding historical and political development and the way the Constitution has changed over time, it hopes to discover more about the evolution and concept of a constitutional identity.

Keywords: constitutional founding; transition; revolution; constitutional change; constitutional identity.

\section{Resumo}

Esse trabalho analisa a fundação constitucional brasileira e uma perspectiva comparada, procurando entender como a identidade da fundação influenciou o desenvolvimento constitucional ao longo das três décadas desde que o documento constitucional foi promulgado. Criando uma ligação entre o desenvolvimento histórico e político da fundação e o modo pelo qual a Constituição mudou ao longo do tempo, espera-se descobrir mais sobre a evolução e o conceito de uma identidade constitucional.

Palavras-chave: fundação constitucional; transição; revolução; mudança constitucional; identidade constitucional.

Como citar esse artigo/How to cite this article: CAVALCANTI, Ana Beatriz Vanzoff Robalinho. Brazil in comparative perspective: the legacy of the founding, and the future of constitutional development. Revista de Investigações Constitucionais, Curitiba, vol. 6, n. 1, p. 11-33, jan./abr. 2019. DOI: 10.5380/rinc.v6i1.59195.

* This paper was first written as a result of a supervised research conducted under Professor Bruce Ackerman at Yale Law School. I am deeply grateful for Professor Ackerman's input, support and encouragement throughout the year I spent as his advisee and research assistant. This paper is but a small example of the many ways in which I have benefited from his scholarship and influence.

** Master of Laws (LL.M) at Yale Law School (New Haven, United States). Master of State Law at Universidade de São Paulo - USP (São Paulo-SP, Brazil). Lawyer and specialized in Constitutional Law. anabeatrizrobalinho@gmail.com. 


\section{CONTENTS:}

1. Introduction; 2. Part I - The constitutional founding of Brazil: transition or revolution? 3. Part II - One World Constitutionalism? Comparing constitutional foundings. II.1. A single path scenario; II.2. Three paths to constitutionalism; 4. Part III - Constitutional narrative and constitutional development; 5. Conclusions. 6. References.

\section{INTRODUCTION}

On May $12^{\text {th }}, 2016$, Brazil watched an unelected president be sworn into office. The last time this happened was on October $2^{\text {nd }}, 1992$, when then Vice-President Itamar Franco assumed the presidency following the suspension of democratically elected Fernando Collor de Mello on corruption charges. A few years further into the past, on March $15^{\text {th }}, 1985$, elected Vice-President José Sarney was sworn in following the unexpected illness of elected President Tancredo Neves. Together, Sarney and Franco ruled the country for seven years out of a decade.

Presidents with little democratic legitimacy have been a commonplace reality since the early days of the Brazilian democratic transition. President Michel Temer's term in office, now approaching its final stretch, may differ in some ways from those early days illegitimate presidential mandates; after all, it is the result of a political crisis affecting a seemingly consolidated democracy. However, to the extent it is the product of a failed electoral system, which fills our (constitutionally empowered) Congress with an unrepresentative collection of politicians, and the consequence of a parliamentary designed Constitution applied to a presidential system, Brazil's current political drama has very deep roots in the tumultuous history of its constitutional founding.

In the present both sides of the political spectrum and all varieties of jurists and political scientists continue to debate the appropriate solution for the current crisis, but they all seem to agree that the answer will involve constitutional change, and of the greatest significance. The call for political reform, from the remodeling of the proportional representation system to the alteration of the very system of government (from presidential to either semi-presidential or parliamentary), will invariably involve extensive changes to the text of the Constitution.

What no one seems to agree on is how. Some argue that only a constitutional convention (which has been called an exclusive constituent assembly) called for the specific purpose of accomplishing political reform could legitimately alter the Constitution to such an extensive degree ${ }^{1}$. Our President himself (a constitutional law professor) has

\footnotetext{
${ }_{1}^{1}$ GIANNETTI, Eduardo. Por uma constituinte exclusiva, Folha de São Paulo, 04/10/2016. Available at: <http:// www1.folha.uol.com.br/opiniao/2016/04/1759180-por-uma-constituinte-exclusiva.shtml>. For a rebuff of this view, see VIEIRA, Oscar Vilhena. Riscos da constituinte exclusiva, Folha de São Paulo, 03/21/2015.Available at: <http://m.folha.uol.com.br/colunas/oscarvilhenavieira/2015/03/1606153-riscos-daconstituinte-exclusiva. shtml>. The juridical theory of an exclusive constituent assembly was first raised by Dilma Rousseff's own
} 
written articles and personally sponsored a constitutional amendment project to promote a new round of constitutional revision, a comprehensive process of constitutional change that the Constitution called for only once, five years after its enactment ${ }^{2}$. Others still insist that a simple constitutional amendment, legally approved by Congress, could legitimately alter even our system of government - while its political opponents claim that such an amendment would violate the Constitution's eternity clause protecting the separation of powers. A final round of contenders insist that a parliamentary system of government could be established by a decision of the Supreme Court (maybe followed by a referendum) ${ }^{3}$.

As we rage war over the appropriate process to achieve our much needed political reform, all eyes are constantly turning to the past, and revising the complex process through which we acquired the system that we have today. The four corners of the political spectrum feel entitled to appropriate the constitutional founding as an argument of their own preferred version of constitutional reform. Two main narratives are dominant.

The first adopts the banner of legal continuity, and insists that only the processes expressively proposed in the written Constitution are adequate and legitimate to resolve the current impasse. These are the contenders of more moderate changes, and believers in the sensibility of elite decision-making. The Congress may deliberate on the subject of a constitutional amendment, the President may conscientiously resign and call for new elections, and even the Supreme Court may legitimately - albeit through an unusual set of circumstances -alter the Constitution to establish a new form of government. But constitutional conventions, revisions, and constitutionally unauthorized referendums are illegal breaks with the existing constitutional order, and with our own traditions in constitutional development ${ }^{4}$.

administration in 2013, following the confederations cup's popular protests (which called, amongst other things, for political reform). The proposal was met with severe criticism from the opposition, and the government backed down after a few months.

${ }^{2}$ TEMER, Michel. Revisão Constitucional? Constituinte?, Revista do Tribunal de Contas da União, v. 29, n. 75 , 1998. On this subject, see also PAIXÃO, Cristiano. Democracia e Constituição: um golpe desconstituinte? JOTA, Democracia e Sociedade, 05/12/2016. Available at: <https://www.jota.info/opiniao-e-analise/artigos/democracia-e-constituicao-um-golpe-desconstituinte-12052016>.

${ }^{3}$ See CARNEIRO, Luís Orlando. STF vai decidir se parlamentarismo pode ser adotado por emenda constitucional. JOTA, Justiça, 03/11/2016. Available at: <https://www.jota.info/justica/stf-vai-decidir-se-parlamentarismo-pode-ser-adotado-por-emenda-constitucional-11032016>.

${ }^{4}$ See HARTMANN, Ivan. Antecipação de eleições gerais é constitucional? Não, Folha de São Paulo, 04/09/2016. Available at: <http://www1.folha.uol.com.br/opiniao/2016/04/1759166-antecipacao-de-eleicoes-gerais-e-constitucional-nao.shtml>. For a rebuff, and a sketch ofthecounter-position describedbellow, see PEREIRA, Thomaz. Antecipação de eleições gerais é constitucional? Sim, Folha de São Paulo, 04/09/2016.Available at: <http://www1.folha.uol.com.br/opiniao/2016/04/1759168-antecipacao-de-eleicoes-gerais-e-constitucional-sim.shtml>. 
The other branch of theories is more enthusiastic about the appeal to popular will in the process of altering our current constitutional commitments. They are the champions of justifying legally unauthorized instruments of more direct democracy and popular participation as means to confer legitimacy to the process of constitutional change. They further believe that the inherent failures of our current representative system largely justify a more direct appeal to the people - even if there is no prediction in the written Constitution for such an appeal. These contenders look to the constitution-making process of 1987-1988 as one built on extraordinary popular participation, which accounts for the progressive character of the Constitution (far more progressive than the political views of the majority of the constituents) and the very legitimacy of our new beginning.

These different visions of the Brazilian founding create different accounts of what are our precedents for constitutional development. In the next few months, one of them will have to prevail, as we are forced to face the need for constitutional reform in the urgent wake of political crisis. Will our traditional narrative of continuity and elite-oriented change once again prevail, as the interim government intends? Or is there time for a different narrative about our constitutional past to shape a new path for our future development?

I cannot predict how this crisis will end. In this paper I hope to show how rethinking our constitutional past can shape the way in which we will advance our constitutional development. I will place Brazil in comparative perspective by showing how the debate advanced in the realm of comparative constitutional law can help us better understand ourselves, as players in the arena of worldwide constitutionalism and within our own borders. In Part I, I will further develop the competing narratives of our constitutional founding. In Part II, I will visit the comparative analysis that can provide me will the tools to suggest the possibility of a new founding narrative for Brazil. In Part III, I will advance the possibilities of this new founding narrative, and how it may help move us beyond our current constitutional problems.

\section{PART I - THE CONSTITUTIONAL FOUNDING OF BRAZIL: TRANSI- TION OR REVOLUTION?}

The middle classes of society had alternated historically between passive service to an agrarian and commercial elite they could not dislodge from the heights of power and futile campaigns to reform the state and establish a regenerate democracy on the North American and Western European model. The military regime had done more for these groups than multiply opportunities of ascension to wealth and power through the officer corps and the civilian bureaucracy. It had provided them with an involuntary political 
education. It had taught them that politics was indeed fate. The newly manifest power of government to make or break the social order - the partial lifting of the blockage imposed on social life by the oligarchy - shook the sense that things could not be other than what they were. It converted people in the politically conscious but unpropertied classes to a deeper uncertainty about what would become of their social world. ${ }^{5}$

In the mid-1980s, Brazilians were unsure about their political future. A dictatorship was declining - even the leaders of the authoritarian regime recognized as much - but what would take its place remained unclear. Some believed politics would return to its old course, with traditional civilian elites reclaiming their rule over a de-politicized majority of citizens; the military leaders themselves hoped to see reestablishment of this scenario ${ }^{6}$. But this was a minority view.

For the most part, people understood that deep structural changes were undergoing Brazilian society. Under twenty years of military rule, Brazil had moved from 55\% rural to $74 \%$ urban $^{7}$. Politics had taken new claims on the popular imaginary. People living in cities were far harder to control than the traditional rural population that voted on whoever their coronel commanded. Furthermore, these once all-powerful elites had already been dislodged from power once - albeit to be replaced by something worse. But why could it not now be something better? ${ }^{8}$ New political elites saw a possibility, never before as concrete, to seize power from those who had ruled the country for our entire republican history. Old political elites understood that they would have to reinvent themselves if they wished to reclaim power.

Both sides still had to deal with the awakening of civil society. As the dictatorship begun to lose steam, social groups on all corners of the country rose to organize their collective demands. The political opposition, or the outsider-elites, was the first to take notice of the potential that lay beneath popular mobilization?. Political leaders in the opposition carefully crafted the connection between congressional and popular

\footnotetext{
${ }^{5}$ Harvard Law School Professor Roberto Mangabeira Unger, on the Brazilian constitutional experience of 1988. UNGER, Roberto Mangabeira. Social Theory: Its Situation and Its Task: a Critical Introduction to Politics, a Work in Constructive Social Theory, [s.I.]: Verso, 2004, p. 71.

${ }^{6}$ PAIXÃO, Cristiano. Direito, política, autoritarismo e democracia no Brasil: da Revolução de 30 à promulgação da Constituição da República de 1988, Araucaria: Revista Iberoamericana de filosofía, política y humanidades, n. 26, p. 146-169, 2011.

${ }^{7}$ Data available at the Brazilian Institute of Geography and Statistics (IBGE). See http://seriesestatisticas.ibge. gov.br/.

${ }^{8}$ For further analysis, see UNGER, Roberto Mangabeira. Social Theory: Its Situation and Its Task: a Critical Introduction to Politics, a Work in Constructive Social Theory, [s.l.]: Verso, 2004.

${ }^{9}$ The first concrete attemps at overthrowing the existing authoritarian regime begun as, following the allowed return of oppositional political parties from illegalities, the 1982 parliament elections provided the opposition with the opportunity to organize itself within the existing institutions. Political leaders for the opposition articulated the movement for direct elections around a proposed amendment to the authoritarian constitution of 1967, which would estinguish the electoral college and allow for the President to be directly (and democratically) elected by the people. The political negotiations surrounding the endorsment of the amendment begun
} 
struggles for the return of democracy, and mobilized the population in the largest social movement in Brazilian history: the Diretas Já, or the movement for direct elections, which took millions to the streets ${ }^{10}$.

The accosted military government, however, was able to resist popular pressure and manipulated congress into rejecting the constitutional amendment that would allow free democratic elections for president for the first time in twenty years. A civilian president approved by the military was indirectly elected by the (regime-controlled) Electoral College, and the military announced the last phase of the "slow and gradual" process of political opening they had initiated - and struggled to control - for the preceding decade ${ }^{11}$. This was the move of the old elites. They hoped to return to a time when the apparent structure of democracy was enough to appease calls for popular engagement in politics.

In early 1987, these two ideologically opposed groups had both earned significant victories. The sudden death of centralist Tancredo Neves lead to the empowerment of a true member of the old regime, who assumed the office of the Presidency. Meanwhile, a progressive minority of new elites became the intellectual leadership of the newly elected (and mostly conservative) Congress. A third political force would be necessary to balance the impasse between these ideological opposites. In a newly established political tradition, popular mobilization tipped the scales, severely undermined the legitimacy of the executive, which began to cave to popular appeals for a new, democratic Constitution ${ }^{12}$.

While the Constituent Assembly was dominated by the main opposition party - which held $52 \%$ of the seats ${ }^{13}$ - the real situation of this democratically elected body was far more complex. A game of musical chairs before the 1986 election had severely deformed the ideological spectrum of the "opposition", with large numbers of previous supporters of the military government fleeting to the new majoritarian party before the election ${ }^{14}$. General political analysis of the composition of the Brazilian Constituent

months any degree of mobilized popular envolvement had taken place. See LEONELLI, Domingos; OLIVEIRA, Dante de. Diretas Já: 15 Meses que Abalaram a Ditadura, Rio de Janeiro: Record, 2004, p. 10-25.

${ }^{10}$ LEONELLI, Domingos; OLIVEIRA, Dante de. Diretas Já: 15 Meses que Abalaram a Ditadura, Rio de Janeiro: Record, 2004.

11 See GASPARI, Elio. O Sacerdote e O Feiticeiro: A Ditadura Encurralada, História e Geografia edition. [s.I.]: Intrinseca, 2014.

${ }^{12}$ On the role of mobilized popular movements in forcing the government to call for the Constituent Assembly, see BARBOSA, Leonardo Augusto de Andrade. História Constitucional Brasileira: mudança constitucional, autoritarismo e democracia no Brasil pós-1964, Brasil: Biblioteca Digital da Câmara dos Deputados, 2012.

${ }^{13}$ MAUÉS, Antônio Gomes Moreira; SANTOS, Elídia Lauris dos. Estabilidade Constitutiocional e Acordos Constitucionais: os processos constituintes de Brasil (1987-1988) e Espanha (1977-1978), Revista Direito FGV, São Paulo, v. 4(2), p. 349-388, 2008, p. 359.

${ }^{14}$ For a full analysis of the redrawing of party lines in the 1986 election, see HAGOPIAN, Frances. "Democracy by Undemocratic Means"? Elites, Political Pacts, and Regime Transition in Brazil, Comparative Political Studies, v. 23, n. 2 , p. 147-170, 1990. 
Assembly reveals that the majority of its members held conservative and elitist views, detached from the appeals of the general public ${ }^{15}$.

A minority of progressive constituents, however, was partially successful in neutralizing the effects of the conservative center by placing emphasis on the work of smaller committees in the drafting of the text, rather than the full membership of the Assembly. Popular participation was also increased through the smaller committees, which could hold public hearings and receive "suggestions" sponsored by civil society. Over 9000 suggestions for the drafting of specific constitutional provisions were presented in the assembly, which resulted in the addition of 122 popular amendments to the body of the text. Through these and other democracy-enhancing mechanisms, a staggering 12 million people are estimated to have participated in the process of constitution-making in Brazil between 1987 and 1988 - roughly $10 \%$ of the voting population ${ }^{16}$.

Meanwhile, the military government sought to minimize damages by exerting pressure in strategic points of the debate within the Assembly, most famously in forcing the approval of a presidential form of government, when a clear majority was in favor of a parliamentary system ${ }^{17}$. The government-controlled coalition also sought to diminish the power of the more democratic small committees in favor of full membership votes (where conservative results were far more likely to occur), and was partially successful ${ }^{18}$.

These unusual processes generated an unusual document. Whereas the Brazilian constitutional text of 1988 showed the marks of the military intervention in several provisions, it also carried far more progressive provisions than the majority coalition aimed for. It has been called a Constitution without winners ${ }^{19}$, and it opened the doors for ideologically opposite appropriation by different groups at different times.

The paradoxical features of our founding have crowded constitutional theory and practice in Brazil with diverging conceptions of the true identity of our system, with profound consequences for the legitimation of constitutional evolution. The dominant traditional narrative has been one of elite dominated continuity, but popular influence

${ }^{15}$ HAGOPIAN, Frances. "Democracy by Undemocratic Means"? Elites, Political Pacts, and Regime Transition in Brazil, Comparative Political Studies, v. 23, n. 2, p. 147-170, 1990.

${ }^{16}$ All the data regarding the so-called popular amendments of the Brazilian constituent process can be found at MICHILES, Carlos. Cidadão constituinte: A saga das emendas populares, [s.l.]: Paz e Terra, 1989.

17 J. LINZ, Juan; STEPAN, Alfred. Problems of Democratic Transition and Consolidation: Southern Europe, South America, and Post-Communist Europe, Baltimore: Johns Hopkins University Press, 1996, p. 170.

${ }^{18}$ The detailed nature of the political moves conservatives and progressives made during the Constituent Assembly was exposed in a series of interviews of prominent members of the constituent congress conducted in 2013 in Brasilia, including former President Fernando Henrique Cardoso and former Supreme Court Justice Nelson Jobim. The interviews were conducted and recorded by members of the study group on the Brazilian Constituent Assembly sponsored by the Brazilian Institute of Public Law (IDP).

${ }^{19}$ See HOLMES, Pablo. A “Agenda Brasil” e os Limites da Nova República: O Paradoxo entre Estabilidade e Mudança na Constituição de 1988, available at: http://www.fd.unb.br/pt/statistics/a-agenda-brasil-e-os-limites-da-nova-republica-o-paradoxo-entre-estabilidade-e-mudanca-na-constituicao-de-1988. 
and rupture have been increasingly featured in narratives about the founding. This shift can be placed in the context of a world phenomenon, in which the analysis of democratic transitions and constitutional foundings is signaling its first moves away from the elitist paradigm that dominated it for the last three decades. The extent of this shift, and its consequences for constitutional legitimacy and evolution, will be explored in Part II.

\section{PART II - ONE WORLD CONSTITUTIONALISM? COMPARING CONSTITUTIONAL FOUNDINGS}

We can make life easy for ourselves by supposing that "constitutionalism" is a "one-size-fits-all" ideal that animates a common project throughout the world. But this seems unlikely (to put it mildly). ${ }^{20}$

In the comparative perspective of the evolution of society - even modern society - the advent of constitutionalism ${ }^{21}$ as a worldwide phenomenon has been both swift and deep. On the one hand, the use of "worldwide", while a generalization, is not entirely misplaced: the presence of constitutionalism is undisputed across the powerful axis of Europe and America, while Asia is held in constant alert by the beacons of India and Japan. On the other hand, by the most generously inclusive accounts, this is a seventy year-old trend ${ }^{22}$.

Through one of the most dynamic periods in human history, constitutionalism became an overfamiliar part of our collective vocabulary. But why? Modern scholars have sought to understand the phenomenon of constitutionalism through the lenses of history, politics, economics and social theory, providing for a large range of rationalizing models that display varying degrees of generalization in unifying too many unique variables into one comprehensive account.

\footnotetext{
${ }^{20}$ ACKERMAN, Bruce. The Rise of World Constitutionalism (Draft in possession of the author), [s.l.: s.n.], 2016, p. 2.

${ }^{21}$ Constitutionalism is a phenomenom which can certainly take more than one meaning. Many conceptions of constitutionalism may come embedded with the influence of other concepts - such as "rule of law" or "democracy". In my dissertation, I will adopt the concept of constitutionalism described by Ackerman - as limits placed on top decision-makers. He notes that "I want to distinguish my inquiry from a larger effort to clarify the broader ideal of the "rule of law." Constitutionalism, as I understand it, involves the imposition of significant legal constraints on top decisionmakers. But the broader "rule of law" ideal deals primarily with the way top decision-makers try to control everybody else." Ibid., p. 6.

${ }^{22}$ Writing for the first time on the project of The Rise of World Constitutionalism nearly twenty years ago, Ackerman urged the reader to look back into the 1930s, and access the prospects of constitutionalism across the world. They were grim, he said, following the collapse of the Weimar Republic and further the development of other nazi-like dictatorships in Europe and even Latin America. Past 60 years, in the mid-1990s, he admired the turn of the world: constitutionalism was a reigning force in the west and beyond. The framework he describes initiated just as the consequences of the intra-war period begun to dissipate. ACKERMAN, Bruce. The Rise of World Constitutionalism, Virginia Law Review, v. 83, n. 4, p. 771-797, 1997, p. 771.
} 
Can we identify with precision the genesis of contemporaryconstitutionalism? The impossible task seems to be finding the one factor present in over thirty ${ }^{23}$ countries in the last seventy years, which allowed for the establishment of constitutionalism in the overall form that we know today. Because we are often seduced by the domino effect of history as an explanation for common events taking place in different locations, the temptation is to look back to where it started ${ }^{24}$.

\section{II.1. A single path scenario}

Naturally, no ordinary set of events stands at the other end of this seven-decade gap; World War II had just swept over the world, with far-reaching consequences in the realm of law. The first constitutions rising from this period - from the allied-imposed documents of Germany and Japan, to the revolutionary Constitution of India, brought about by the British retreat following the war efforts - have profound causal ties to the events of the largest armed conflict in human history.

The influence of the war should not be underestimated, but it is easy to overextend it, also. The basic characterization of constitutionalism as a response to the horrors of war could easily unifyits world prominenceunder thebanner of the entrenchment of basic human rights ${ }^{25}$. Western European constitutions that followed the German charter, even by a couple of decades, naturally fit into this narrative; after all, they either experienced the effects of war directly (like France and Italy) or indirectly, through the spread of authoritarian dictatorships of the Nazi variety (like Portugal and Spain). Latin America and Eastern Europe, which did not enter their own constitutional experiences until the 1980s, can also take part in the analogy through their own struggles with the excesses of dictatorship ${ }^{26}$.

\footnotetext{
${ }^{23}$ Thirty is actually Huntington's count for the Third Wave transitions - between 1974 and 1990. If the period is extended to the immediate post-war period, many more constitutional experiences would have to be factored in. HUNTINGTON, Samuel P. The Third Wave: Democratization in the Late 20th Century, Norman: University of Oklahoma Press, 1993, p. xii.

${ }^{24}$ Huntington allowed for two explanations for the third wave of democratization that could fit into this paradigm: the single cause and the snowballing effect. Ibid., p. 32-33.

${ }^{25}$ For a description of the trend of modern German constitutionalism as a reaction to the Nazi past - and a strong rebuff thereof - See HAILBRONNER, Michaela. Rethinking the rise of the German Constitutional Court: From anti-Nazism to value formalism, International Journal of Constitutional Law, v. 12, n. 3, p. 626-649, 2014.

${ }^{26}$ The flow of these ideas - from the old to the new world, and from the post-war to the post-cold war - is particularly noticeable in two countries that will be explored here: Spain and Brazil. In the former, the concept of neoconstitutionalism was first developed to explain the new face of Spanish constitutionalism: a reaction to the horrors that preceded, caused and followed through the many wars the country faced in the first half of the 20th century, and which the new constitutional order brought to a much expected end, with the promise of entrenching fundamental rights and severely restraining government in the name of individual liberties. See CARBONELL, Miguel. Neoconstitucionalismos, Madrid:Trotta, 2005. In post-1988 Brazil, neoconstitutionalism is a school of thought of remarkable influence, championed first and foremost by Supreme Court Justice Luís Roberto Barroso. In the Brazilian context, neoconstitutionalism has been used to justify the unprecedented rise of the judiciary - and specially the Supreme Court - in the last decades, as a natural consequence of the
} 
But the legacy of World War II was not a key element in the last generation's constitutional transformations in Latin America and Eastern Europe.In the late 1980s, the world had moved past the legacy of totalizing war; new developments were pushing national political agendas through international pressures, such as the imminent collapse of the Soviet Union and the end of the Cold War and the devastating effects of economic crises. Here, unlike the spirit of earlier post-war constitutions, the economy was at the forefront of political concerns, and no constitutionalizing effort could be fulfilled without addressing firmly the goals of stability and prosperity.

Samuel Huntington ${ }^{27}$ acknowledged these fundamental distinctions in separating the immediate post-war period from more modern attempts at constitutionalism: while the former was recognized as a portion of a short Second Wave of world-wide democratization, the Third Wave began in 1974 with the Portuguese revolution, and encompassed the contemporary efforts of Southwestern Europe, Latin America and Post-Communist Europe. These periods did not merely group new democratic and constitutional experiences chronologically, but attributed to them specific motivating rationalities ${ }^{28}$.

These (different levels of) generalizations reveal a comprehensible urge, within the field of comparative public law, to discover commonalities that could bestowthe constitutional enterprise with some level of systematization and comparative logic, while informing, in the national sphere, the constitutional narrative ${ }^{29}$ of the founding and generally of each system's development. The studies, each in its particular way, have shared the common enterprise of identifying a unifying factor capable of explaining the phenomenon of global constitutionalism. This is not to say, of course, that any scholar could expect the complex occurrence of constitutionalism to be fully explained by a single factor, no matter how significant; rather, these studies have searched for a common logic capable of serving as the main engine for the development of constitutional democracies around the world.

\footnotetext{
constitutional duty to overcome the excesses of the dictatorship through the defense of fundamental rights. See BARROSO, Luís Roberto. El neoconstitucionalismo y la constitucionalización del derecho, México: UNAM, p. 33, 2008. For a criticism of neoconstitutionalism in the brazilian context, see SARMENTO, Daniel. O neoconstitucionalismo no Brasil: riscos e possibilidades. In: QUARESMA, Regina; OLIVEIRA, Maria Lúcia de Paula; OLIVEIRA, Farlei Martins Riccio de (Orgs.). Neoconstitucionalismo. Rio de Janeiro: Forense, 2009. p. $267-302$.

${ }^{27}$ HUNTINGTON. The Third Wave. Democratization in the Late 20th Century. Norman: University of Oklahoma Press, 1993.

${ }^{28}$ Whereas Huntington continuously focuses on external factors to explain the motivations of his democratization waves, he acknowleges that the effects of the II World War in 1940s and 1950s Constitutions gave way to new first orders of concern - mainly economic - starting in the 1970s. Ibid., p. 20-45.

${ }^{29}$ The recurrent use of narrative in the next several pages will constantly be aligned with the familiar idea of a professional narrative, whereas it can be understood as more than just a tool lawyers use in making legal arguments. Most importantly, narrative will represent something which is not the same as history, but nonetheless intrinsically related to it: the use of history and its knowledge for a particular purpose, of interpreting and understanding the evolution of law, its relation to society and the mutual layers of influence between the legal, the political and the social. I owe this observation to Professor Owen Fiss, who pointed out the importance of defining narrative in this context during a classroom discussion.
} 
Huntington's The Third Wave ${ }^{30}$ has been influential enough to start a trend of its own in the arena of comparative political science; he places great emphasis on the beliefs and actions of political elites in determining the likelihood of the democratic outcome. The influences upon elites explored in the book range from internal governmental performance to external pressures of economic and political nature. In all instances, his approach highlights a narrative of negotiated transition that has little to do with the people.

Others have followed in Huntington's footsteps. Juan Linz and Alfred Stepan wrote on the advantages of negotiated transitions in ensuring the necessary conditions for the consolidation of democracy ${ }^{31}$, whereas Andrew Arato took a step further in advocating for the superiority of a round-table model of elite negotiations in the constitution-making process of new democracies ${ }^{32}$. In fitting Third Wave constitutional cases into the single transition scenario (as by-products of the transition to democracy), Ran Hirschl developed a theory of constitutionalization for the purpose of hegemonic preservation, pointing to the interests of elites in maintaining the status quo ${ }^{33}$.

Third wave scholarship thus has strived to depict the modern impulse towards constitutionalism as a consequence of diverging factors' influences on political elites. Whether the main concern is within politics, economics or social preservation, the unifying aspect of transitions into constitutional democracies lies within the inclinations of a few politically prevalent groups. The will of a few controls the destiny of many.

From a descriptive point of view, they are most likely correct. Political elites are charged with the power of government, and it is in their negotiating tables that government is created, shaped and passed into new hands. The problem with this diagnosis is that third wave scholarship is trying to explain how and why constitutional democracies have been created, and not why they are legitimate. As we move into the realm of legitimacy, we no longer take how a constitutional system came to be as the question, but as $a$ question - whose answer is designed to clarify yet another inquiry.

\section{II.2. Three paths to constitutionalism}

Bruce Ackerman has sought to answer the second question through the first, claiming that the legitimating logic of a constitutional system is related to its foundation. This shift in the central inquiry of the enterprise has placed him in direct

\footnotetext{
${ }^{30}$ HUNTINGTON. The Third Wave. Democratization in the Late 20th Century. Norman: University of Oklahoma Press, 1993.

${ }^{31} \mathrm{~J}$. LINZ, Juan; STEPAN, Alfred. Problems of Democratic Transition and Consolidation: Southern Europe, South America, and Post-Communist Europe. Baltimore: Johns Hopkins University Press, 1996.

${ }^{32}$ ARATO, Andrew. Civil Society, Constitution, and Legitimacy. Lanham, MD: Rowman \& Littlefield Publishers, 2000.

${ }^{33}$ HIRSCHL, Ran. Towards Juristocracy: The Origins and Consequences of the New Constitutionalism. Cambridge: Harvard University Press, 2007.Cambridge: Harvard University Press, 2007.
} 
opposition to third wave scholarship, as the question of legitimacy refuses to yield to a single answer. Instead, he expressively echoes Max Weber ${ }^{34}$, who established three pure types of legitimate domination, and offers a three-path model to explain the rise of constitutionalism ${ }^{35}$.

Ackerman builds upon Weber's famous ideal types of legal, traditional and charismatic authority by introducing into the framework the creative element, which is the distinctive appeal of constitutionalism ${ }^{36}$. Ackerman is concerned with how authority (in the Weberian sense of probability that a command will be obeyed ${ }^{37}$ or in a more modern sense of legitimation as respect-worthiness ${ }^{38}$ ) is first established, rather than how it is maintained over time ${ }^{39}$.

Weber's analysis, on the other hand, is less concerned with the genesis of power than it is with its conservation. Kalyvas' study of Weber seems to suggest that his greatest shortcoming was to keep his analysis on the level of normal politics. Ackerman's appeal to extraordinary, or constitutional politics ${ }^{40}$, allow especially for the revitalization of charisma as a creative force in the establishment of legitimate authority ${ }^{41}$.

This accounts for Ackerman's great emphasis on the model of revolutionary constitutionalism, which will be joined by pragmatic adaptations and elite constructions as the three paths towards legitimate constitutional systems. Revolutionary paths

\footnotetext{
${ }^{34}$ See generally WEBER, Max, Economy and Society: An Outline of Interpretive Sociology. [s.l.]: University of California Press, 1978.

${ }^{35}$ ACKERMAN, Bruce. The Rise of World Constitutionalism. (Draft in possession of the author), [s.l.: s.n.], 2016.

${ }^{36}$ For a detailed development of the Ackerman-Weber relationship, see KALYVAS, Andreas. Democracy and the Politics of the Extraordinary: Max Weber, Carl Schmitt, and Hannah Arendt. Cambridge: Cambridge University Press, 2009, p. 65-78, 163-174.

${ }^{37}$ WEBER, Max. Economy and Society: An Outline of Interpretive Sociology. [s.I.]: University of California Press, 1978. p. 212.

${ }^{38} \mathrm{See}$, bellow, the development of this concept of constitutional legitimacy in III.

${ }^{39}$ This is not to say Ackerman ignores the longer view on whether a certain constitutional system will survive past its first generation - this is certainly part of what leads him to classify his chosen case-scenarions as "success cases". Rather, Ackerman's diagnosis identifies the special challenges generated by different paths to constitutionalism, but does not prescribe a formula to overcome them. He states that "At the same time, I am not trying to provide a complete causal account of the conditions under which political systems sustain themselves over time. Even though a constitutional regime generates broad belief in its legitimacy, it may be crushed by military defeat or economic depression or some other catastrophe. The reverse may also be true: virtually everybody may believe that the Constitution is a sham, but they continue to support the system as long as it delivers prosperity and national security. Nevertheless, the presence or absence of a widespread belief in constitutional legitimacy can play an important - sometimes, all-important - role in shaping political and social life. So the different dynamics that may generate such commitments are worthy of sustained study". ACK ACKERMAN, Bruce. The Rise of World Constitutionalism. (Draft in possession of the author), [s.l.: s.n.], 2016. p. 7-8.

${ }^{40}$ For a detailed view of Ackerman's concept of constitutional politics in the framework of his dualist democracy, see generally ACKERMAN, Bruce. We the People, Volume 1: Foundations. Cambridge: Belknap Press, 1993. ${ }^{41}$ On the revival of charisma through the concept of extraordinary politics, see particularly KKALYVAS, Andreas. Democracy and the Politics of the Extraordinary: Max Weber, Carl Schmitt, and Hannah Arendt. Cambridge: Cambridge University Press, 2009. p. 163-186.
} 
will base legitimacy primarily on charisma. The charisma in Ackerman's model is not of the ruler ${ }^{42}$, but of the organized popular movement that channels the will of the people into new constitutional achievements ${ }^{43}$. This allows for a system that enjoys broad democratic legitimacy - if only it can keep the ghost of totalitarianism at bay.

Pragmatic adaptations result from the cooptation of popular movements by the establishment, which generates constitutional reforms to accommodate popular demands. The source of legitimacy here is tradition, as the people give a vote of confidence to the government that just demonstrated once more statesmanship abilities and responsiveness. This will allow for the legitimacy of the system so long as the people can keep such faith.

Elite constructions spring from the absence of popular movements, as a vacuum of power is not filled by the masses - that sit in passivity - but by a group of elitist outsiders that make their way into power and establish a new constitutional order. The Weberian parallel here is to the legitimacy of rational bureaucracy, which suggests a legal system that is legitimated by itself. Ackerman's theory for the legitimating source of elitist new beginnings is not entirely clear, but he recognizes this paradox in pointing to the authenticity problem of elite constructions.

Ackerman's deconstruction of the third wave model begins at the suggestion of a three-tiered pathway, rather than a single-answer scenario. But popular mobilization is at the heart of his endeavor, and the chief preoccupation of the first volume of his series. Already in this first analysis Ackerman shows us how several third wave cases are actually examples of the revolutionary path, such as South Africa and Israel. He creates another category for countries of the commonwealth, differentiating pragmatic adaptations (which necessarily must be motivated by popular uprising) from elite constructions. His moves make the path towards elite constitutionalism quite straighter than previous analysis would suggest.

And with good reason. Even in the very limited time Ackerman dedicates to exploring elite construction as a model in the first volume of this series, it is clear the achievement of legitimacy is the most challenging in this scenario. The authenticity problem looms over the few actual elite construction cases Ackerman explores, with

\footnotetext{
${ }^{42}$ For a critique of Weber's individualistic treatment of charismatic power, see lbid.

${ }^{43}$ Whereas Ackerman also recognizes the importance of the charismatic leaders - and their significant amount of influence in the development of organizational charisma - the stories of revolutionary success seem to be the ones in which leadership charisma is channeled into a broader movement's organizational charisma. Attempts to divorce leadership charisma from its popular mobilized roots, on the other hand, seem to end in failure. He observes that charismatic leaders "owed their position to their symbolic centrality in the revolutionary narrative that movement activists tell themselves about the meaning of their struggle. To put the point in non-charismatic terms: Symbolic leaders found themselves in the right place at the right time - at the head of demonstrations of mass resistance at particular moments which achieve epic status in the narrative that ordinary people tell themselves about the larger revolutionary struggle." See ACKERMAN, Bruce. The Rise of World Constitutionalism. (Draft in possession of the author), [s.l.: s.n.], 2016. p. 52.
} 
Spain and Japan facing challenges that threaten the very life of their current constitutional orders. Germany, on the other hand, stands as a counter-example of legitimacy and stability in the paradigm of elitist constitutionalism, for reasons that remain to be fully explored ${ }^{44}$.

Revolution, elite construction, pragmatic adaptation: Ackerman offers a new realm of possibilities for the exploitation of the legitimate establishment of new constitutional orders. Whether or not this will prove a sufficiently comprehensive model in comprising the complexities of modern constitutionalism, it has raised the fundamental issues: not only that a single legitimating logic is entirely unsatisfactory in an effort to explain the constitutional struggles of a large group of countries, but also that different foundational narratives will provide for distinctive legitimation problems within each country, with remarkable consequences for the very identity of the constitutional systems.

A very interesting consequence of these findings was explored by Ackerman in a recent paper, in which he suggested that the diverging paradigms for legitimate constitutionalism within the European union threaten its capacity to solve constitutional issues ${ }^{45}$. According to Ackerman:

The leading nations of Europe come to the union along different paths: the constitutions of Germany and Spain are elite constructions; France, Italy and Poland are revolutionary achievements; and Great Britain emerges from an insider tradition. Little wonder, then, that these countries have trouble finding a common pathway to a more perfect union. The French and Italians and Poles are open to transformative appeals to the People of Europe; the British prefer muddling through; and the Germans are utterly perplexed by the very idea that either political elites or mobilized movements may legitimately repudiate foundational constitutional commitments. ${ }^{46}$

There are two fundamental suggestions in Ackerman's reasoning, and both will be relevant in returning to the analysis of the Brazilian case in the following sections. The first is the idea that different paths to constitutionalism will influence the creation of a particular way to solve constitutional problems - the notion that a certain foundational experience will create a certain culture for constitutional development. The second is its consequence: the problems which arise from the inheritance of conflicting

\footnotetext{
${ }^{44}$ Ackerman seems to concede to the diagnosis that the German Constitutional Court had a lot to do with the rise of the (elite constructed) constitution to the center of the reconstructed political order. But he leaves the analysis of the reasons and means for this occurance for the second volume. Ibid., p. 30-31.

${ }^{45}$ ACKERMAN, Bruce. Three Paths to Constitutionalism - and the Crisis of the European Union. British Journal of Political Science, v. 45, n. 4, p. 705-714, 2015.

${ }^{46}$ ACKERMAN, Bruce. Three Paths to Constitutionalism - and the Crisis of the European Union. British Journal of Political Science, v. 45, n. 4, p. 705-714, 2015. p. 8.
} 
paradigms, which cannot even be properly diagnosed until we can dispense with the idea of constitutionalism as a one-size-fits-all ${ }^{47}$ phenomenon.

I have argued that the Brazilian constitutional system faces deep problems of self-understanding because of the heavy influences of two contrasting paradigms for constitutional development. In Part III will explore further the relationship between the founding narrative and the paradigm for constitutional development, in constitutional theory in general and in Brazil in particular. I will finally analyze how these problems may affect the future of Brazilian constitutionalism, and how we might move beyond the impasse.

\section{Part III - Constitutional narrative and constitutional development}

No set of legal institutions or prescriptions exists apart from the narratives that locate it and give it meaning. For every Constitution there is an epic, for each Decalogue a scripture. Once understood in the context of narratives that give it meaning, law becomes not merely a system of rules to be observed, but a world in which we live in. ${ }^{48}$

A Constitution is defined by its narrative. The narrative informs the animus that holds it upward and pushes it forward. In describing the importance of narrative, Robert Cover claimed that every version of the constitutional framing creates a new text ${ }^{49}$. The narrative, thus, has the upper hand; the text must change to adapt to it, and not the other way around. The idea of narrative is rich because it embodies more than a story about how the Constitution came to be, sometimes fifty, sometimes two hundred years in the past. It informs, moreover, a compromise, a project, that extends over time. It tells us why we committed ourselves to something - and not just what we committed ourselves to - thus helping to justify why we stick to it.

A constitutional narrative is therefore part of the constitutional culture, a set of extrajudicial beliefs that provides guidance and constraints upon constitutional law ${ }^{50}$. It constrains because it provides for a certain way to do things, built upon experience extending sometimes for decades, sometimes centuries. To try and do things differently is a challenge no single lawyer or scholar could take up ${ }^{51}$. It is instead the role of the collective, of an entire generation at times, to change the way that things are done. We

\footnotetext{
${ }^{47}$ ACKERMAN, Bruce. The Rise of World Constitutionalism. (Draft in possession of the author), [s.l.: s.n.], 2016. p. 1.

${ }^{48}$ COVER, Robert M. Foreword: Nomos and Narrative. Harvard Law Review, v. 97, 1983, p. 4-5.

${ }^{49}$ COVER, Robert M. Foreword: Nomos and Narrative. Harvard Law Review, v. 97, 1983, p. 5.

${ }^{50}$ See POST, Robert C. Fashioning the Legal Constitution: Culture, Courts, and Law. Harvard Law Review, v. 117, p. 4, 2003.

${ }^{51}$ ACKERMAN. We the People, Volume 1: Foundations. Cambridge: Belknap Press, 1993. p. 39.
} 
are, at the same time, guided by certain practices and beliefs, a certain language ${ }^{52}$ that we follow because we believe it must be followed, because following it is what cloaks our acts with authority and induces respect and obedience.

In this sense, narrative and culture relate deeply to the patterns of constitutional legitimacy. Frank Michelman defined legitimacy as respect-worthiness and asserted that in a constitutional system, people experience pressure to support laws they do not agree with ${ }^{53}$. Notice that these are not laws that violate the Constitution, but valid laws that violate instead a sense of fairness, or justice, that drives our individual beliefs. Given that no comprehensive set of laws can appeal equally to all the members of a pluralistic society, what feature of the constitutional system provides respect-worthiness? This binding virtue of the constitutional system, when faced with the impossibility of consensus on substance, can only take place in a content-independent scenario.

Content-independent, as I understand it, is not the same as process-based, and not merely author-based either ${ }^{54}$. Rather, it is about the ways in which we can deal with disagreement (and not what we can agree on). Content-independent accounts of legitimacy build upon narrative for several reasons. For one, narrative provides the basis for the idea of continuity, evolution and progress $s^{55}$. Understanding the commitments and promises of the founding generation can inspire people living in different times to build upon those ideals, and cast light on the way that things are done.

However, the People need more than an inspiring project to believe in their Constitution; they need to be shown that such a project is being slowly implemented, and that there is room for growth and change in the future. If constitutional legitimacy is the feature that allows us to cope with laws we don't agree with, then we must believe that the possibility of changing things in the future is viable, and that we can persuade others to accept our views ${ }^{56}$; looking at the Constitution that exists today and imagining the Constitution that it could be is an exercise of hope ${ }^{57}$, and such hope is

\footnotetext{
${ }^{52}$ For one version of constitutional language see BOBBITT, Philip. Constitutional Fate: Theory of the Constitution. Nova York: Oxford University Press, 1984.

${ }^{53}$ MICHELMAN, Frank I. Is the Constitution a Contract for Legitimacy. Review of Constitutional Studies, v. 8, p. $128,2003$.

${ }^{54}$ See Jack Balkin's interpretations of Michelaman in BALKIN, Jack M. Respect-Worthy: Frank Michelman and the Legitimate Constitution. Tulsa Law Review, v. 39, p. 485, 2003.

${ }^{55}$ For a better development of the idea of the Constitution as a legitimacy project, see BALKIN, Jack M. Living Originalism. Cambridge: Belknap Press, 2014.

${ }^{56}$ For an account of this notion of legitimacy in the context of democratic constitutionalism, see POST, Robert; SIEGEL, Reva B. Democratic Constitutionalism. In: SIEGEL, Reva B.; BALKIN, Jack M. (Orgs.). The Constitution in 2020. Nova York: Oxford University Press, 2009, p. 25-34.

${ }^{57}$ Professor Sanford Levinson would, on the other hand, call this faith, and develop its part in maintaining constitutional legitimacy using the notion of interpretative protestantism. He advocates that only by interpreting the Constitution for ourselves can we cope with the injustice of the meanings provided by a central institution, such as the Supreme Court. By believing the real Constitution is the one that we see, we hope to persuade
} 
reinforced when we understand how we can move forward (even when we don't know when).

If we are to see the Constitution as a project, then we must understand how it came to be, what kind of political pact it created and ratified, how it relates to the story of our people. If, furthermore, we accept the constitutional spirit of our times and believe in the concept of popular sovereignty, we must understand how the Constitution claimed authority to speak in the name of the People, to bind them to rules they do not always, in their private realms of morality and conscience, agree with.

But narrative also supplies the culture, the practices and languages that secure our own possibilities of constitutional change, and the knowledge about how a particular constitutional order conducts disagreement about its laws. It shows what our possibilities and mechanisms of persuasion are, and allows us to assess how great a disagreement we can live with based on how much we can ever expect to change.

We are deeply bounded both by the idea of authority and endurance of the rule of law and to our commitment to pluralism and democracy. A constitutional narrative can help reconcile these paradoxical ideals by providing us with tools to commit to something while coping with disagreement, in a way that is best suited to our history, our understandings about the law and our traditions. Narrative does not only tell us where we are going, but why we are going and how to get there ${ }^{58}$.

The varying layers of narrative provided by the different efforts at rationalizing constitutionalism on a world level, therefore, have far greater consequences that mere reclassification on the comparative sphere. They do prescribe caution in the comparative exercise, as modern scholars increasingly show that you need more than the fact that both texts are "constitutions" to place them in comparative perspective. Some constitutional systems, by virtue of factors that escape the traditional boundaries of geography, common culture or language, are more compatible with one another because they are informed by a similar legitimating logic. That is the problem Ackerman identified in Europe, where a novel exercise at cross-continental constitutionalism must overcome the incompatible constitutional heritages that spring from histories of the different nations seeking to be united under one constitutional system.

Furthermore, the consequences of narrative re-telling are also deep within the national sphere. The way a country understands its own Constitution will have

\footnotetext{
others, and especially those with the coercive power to determine meaning, to see the world as we do. See LEVINSON, Sanford. Constitutional Faith. 2. ed. Princeton: Princeton University Press, 2011.

${ }^{58}$ Reva Siegel observes that "It is through the past that we make pragmatic judgments about the ways we can best realize constitutional commitments and values in the present, and by appeal to the past that we know ourselves as a collective subject acting in history, united imaginatively and ethically across generations as well as communities. Collective memory thus plays a central role in constitutional reason". SIEGEL, Reva B. She the People: The Nineteenth Amendment, Sex Equality, Federalism, and the Family. Harvard Law Review, v. 115, n. 4, p. 947-1046, 2002.
} 
profoundeffects on the way it will struggle to maintain the system's legitimacy over time. It will affect the way legal arguments are made, the way the Constitution can be altered, the substance of constitutional developments ${ }^{59}$. As new stories are told about the Constitution as a project, new goals will be $\operatorname{set}^{60}$.

Both aspects of this analysis influence Brazil's constitutionalism.The ambiguous nature of our constitutional founding allows no easy categorization to be sketched regarding our place in a worldwide constitutional order. To make matters worse, our two chief constitutional fathers - the systems from which we draw heavier influences - are modeling opposites in the discussed scenario: Germany is a clear elite construction case, while the United States is a paradigmatic contender of revolutionary constitutionalism.

Within our own constitutional history, we can hardly grasp what is our precedent for constitutional evolution and development. Are we a classic elite construction model, built on the sensibility of elites and in the absence of popular mobilization? Or is our unconventional model of non-partisan popular mobilization an expression of revolutionary constitutionalism? As we go forward and face the political turmoil that threatens our young democracy, it becomes paramount to grasp what kind of constitutional practice or process we are likely to embrace in a new moment of crisis.

The final question is then this: is it a choice or a necessity? Given the power that lies in the possibility of narrative retelling, can we seek to place our founding in a different light? The ever-specifying way in which efforts in comparative law offer diverging views of constitutionalism across the world suggest that to every misdiagnose in the realm of legitimating possibilities there is a new chance for the rebuilding of constitutional history. One could hardly understand the complexities of India or modern day Poland by looking at the behavior of political elites alone in the process of crafting a new constitutional order ${ }^{61}$.

Brazil could be such a case. Our founding document is filled with promises for democracy, progress, equality and social justice that can be inspired into reality or read as dead letter. These achievements lie in the text and in the spirit of the Constitution rightly understood ${ }^{62}$ - and await an interpretative attitude compatible with the task of

\footnotetext{
${ }^{59}$ Reva Siegel observes, hince, that "By telling stories about a common past, a group can constitute itself as a group, a collective subject with certain experiences, expectations, entitlements, obligations, and commitments. The stories that help forge group identity also supply structures of ordinary understanding, frameworks within which members of a society interpret experience and make positive and normative judgments concerning it." SARAT, Austin; KEARNS, Thomas R. History, Memory, and the Law, [s.I.]: University of Michigan Press, 2009, p. 161.

${ }^{60}$ BALKIN, Jack M. Constitutional Redemption: Political Faith in an Unjust World. Cambridge, Mass: Harvard University Press, 2011.

${ }^{61}$ For a brief overview, see ACKERMAN, Bruce. Three Paths to Constitutionalism - and the Crisis of the European Union. British Journal of Political Science, v. 45, n. 4, p. 705-714, 2015.

${ }^{62}$ Akhil Amar has used the Declaration of Independence to show that a text of constitutional order can be read and praised, but still not understood if one is not willing to give it the right interpretative spirit in AMAR,
} 
realizing them.As we refuse to embrace the unusual set of circumstances that provided for an (almost) new beginning in our society, thus forsaking allegiance to the social vision the political elites thought they were enacting (but in reality weren't) ${ }^{63}$, we deny ourselves the source of inspiration that can guide our constitutional project. With no basis to justify constitutional evolution that pushes against the limitations of old precedents and traditions, the professional narrative is forced back into the discourse of legal continuity, blurring the innovative and the progressive (and yes, the revolutionary) in our constitutional commands with the distorted lenses that try to make them a logic consequence of what came before.

Consequently, a misguided picture of our goals within the constitutional system cannot inspire - or justify - building a legal culture that can accordingly bring our constitutional previsions into reality. Conservative or past-oriented approaches to the techniques of constitutional interpretation, the possibilities of constitutional amendment and revision, and the scope (and legitimacy) of informal changes halt our constitutional development, or else condemn it as illegitimate. And this of course especially relevant as we face the need for significant constitutional change in the near future.

A close look at restricting laws and judicial precedents would show how ungenerous "interpretations" of the Constitution have frozen social progress and the advancement of democracy and civil liberties in our constitutional development. While this tendency has been somewhat reversed within the judiciary in the last decade, the general trend continues to point towards containing the effects of the constitutionalizing revolution of law that have resulted from the combination of the abstract comprehensiveness (and progressive character) of the Constitution and the rise of the judiciary to the center of political consequence.

Until we can reconcile the ongoing exercise of responsiveness the Constitution must undertake in a democratic setting with our true sources of founding legitimacy, our constitutional development will continue to fall short in both theory and practice. If the last thirty years of constitutional development are faced with an eye on the binding precedents and ideals of previous regimes, we will continue to be unable to justify the direction and scope of our constitutional evolution. But if we can understand 1988 as an enterprise that tried (and partially succeeded) in breaking with the past, we may learn to interpret and apply our Constitution in ways that redeem the revolutionary commitments of the Brazilian founding.

Akhil Reed, The Consent of the Governed: Constitutional Amendment outside Article V. Columbia Law Review, v. 94, n. 2, p. 457-508, 1994, p. 457. Professor Amar's work is filled with such attempts at encountering the right light to shine on the Constitution - through the use of history and beyond.

${ }^{63}$ On the discrepancies between the political views of the majority of the constituents and the pacts translated into constitutional norms, see SARMENTO, Daniel. 21 Anos da Constituição de 1988: a Assembleia Constituinte de 1987/1988 e a Experiência Constitucional Brasileira sob a Carta de 1988. Dados, v. 29, n. 2, 2009. 
As our democracy faces new challenges with the current political crisis, proposals such as this move to the forefront of constitutional theory. We are facing several possible paths of constitutional change. I cannot predict which one we will take, or even which one we should. What I hoped to convey is that the best possible path will be one that can connect our past to our future, and renew our connection to our constitutional system.

\section{CONCLUSION}

Brazilian constitutional theory is ill equipped to deal with the current political crisis, the greatest since our redemocratization process in 1983-1988. Apart from the shortcomings of the political system, which range from the inadequate electoral laws to the persisting heritage of patriarchy, we are unable to make proper use of the weapons we have. The achievements of 1988 could be lost long before we take the time to properly understand them. As we face the need for constitutional change - sooner, perhaps, than we expected - we must come to terms with the reality of the system we established, if we are to preserve its spirit in the face of shifting times.

The first step is to come to terms with the system we created, its origins and its purpose, and how we came to accept it as legitimate; it will help us both to understand how to change it and which process is more adequate in our constitutional tradition. This is where I hoped to contribute. I don't believe our traditional constitutional narrative and resulting moderate exercise of transformative politics will suffice in bringing us out of our current crisis. Nevertheless, I believe an unconventional arrangement must be legitimized by a better understanding of our constitutional history in order to gain the authority to sustain a new political landscape for the future of Brazil.

\section{REFERENCES}

ACKERMAN, Bruce. The Rise of World Constitutionalism. (Draft in possession of the author), [s.l.: S.n.], 2016.

ACKERMAN, Bruce. The Rise of World Constitutionalism. Virginia Law Review, v. 83, n. 4, p. $771-$ 797, 1997.

ACKERMAN, Bruce. Three Paths to Constitutionalism - and the Crisis of the European Union. British Journal of Political Science, v. 45, n. 4, p. 705-714, 2015.

ACKERMAN, Bruce. We the People, Volume 1: Foundations, Cambridge: Belknap Press, 1993.

AMAR, Akhil Reed. The Consent of the Governed: Constitutional Amendment outside Article V.

Columbia Law Review, v. 94, n. 2, p. 457-508, 1994. 
ARATO, Andrew. Civil Society, Constitution, and Legitimacy. Lanham, MD: Rowman \& Littlefield Publishers, 2000.

BALKIN, Jack M. Constitutional Redemption: Political Faith in an Unjust World. Cambridge, Mass: Harvard University Press, 2011.

BALKIN, Jack M. Living Originalism. Cambridge: Belknap Press, 2014.

BALKIN, Jack M. Respect-Worthy: Frank Michelman and the Legitimate Constitution. Tulsa Law Review, v. 39, p. 485, 2003.

BARBOSA, Leonardo Augusto de Andrade. História Constitucional Brasileira: mudança constitucional, autoritarismo e democracia no Brasil pós-1964. Brasília: Biblioteca Digital da Câmara dos Deputados, 2012.

BARROSO, Luís Roberto. El neoconstitucionalismo y laconstitucionalización del derecho. México: UNAM, 2008.

BOBBITT, Philip. Constitutional Fate: Theory of the Constitution. Nova York: Oxford University Press, 1984.

CARBONELL, Miguel. Neoconstitucionalismos. Madrid:Trotta, 2005.

CARNEIRO, Luís Orlando. STF vai decidir se parlamentarismo pode ser adotado por emenda constitucional. JOTA, Justiça, 03/11/2016. Available at: <https://www.jota.info/justica/ stf-vai-decidir-se-parlamentarismo-pode-ser-adotado-por-emenda-constitucional-11032016>.

COVER, Robert M. Foreword: Nomos and Narrative. Harvard Law Review, v. 97, 1983.

GASPARI, Elio. O Sacerdote e O Feiticeiro: A Ditadura Encurralada, História e Geografia edition. [s.I.]: Intrinseca, 2014.

GIANNETTI, Eduardo. Por uma constituinte exclusiva. Folha de São Paulo, 04/10/2016. Available at: <http://www1.folha.uol.com.br/opiniao/2016/04/1759180-por-uma-constituinte-exclusiva. shtml>.

HAGOPIAN, Frances. "Democracy by Undemocratic Means"? Elites, Political Pacts, and Regime Transition in Brazil. Comparative Political Studies, v. 23, n. 2, p. 147-170, 1990.

HAILBRONNER, Michaela. Rethinking the rise of the German Constitutional Court: From anti-Nazism to value formalism. International Journal of Constitutional Law, v. 12, n. 3, p. 626-649, 2014.

HARTMANN, Ivan. Antecipação de eleições derais é constitucional? Não. Folha de São Paulo, 04/09/2016. Available at: <http://www1.folha.uol.com.br/opiniao/2016/04/1759166-antecipacao-de-eleicoes-gerais-e-constitucional-nao.shtml>.

HIRSCHL, Ran. Towards Juristocracy: The Origins and Consequences of the New Constitutionalism, Cambridge: Harvard University Press, 2007. 
HOLMES, Pablo. A “Agenda Brasil” e os Limites da Nova República: O Paradoxo entre Estabilidade e Mudança na Constituição de 1988. Available at: <http://www.fd.unb.br/pt/statistics/a-agenda-brasil-e-os-limites-da-nova-republica-o-paradoxo-entre-estabilidade-e-mudanca-na-constituicao-de-1988>.

HUNTINGTON, Samuel P. The Third Wave: Democratization in the Late 20th Century. Norman: University of Oklahoma Press, 1993.

J. LINZ, Juan; STEPAN, Alfred. Problems of Democratic Transition and Consolidation: Southern Europe, South America, and Post-Communist Europe. Baltimore: Johns Hopkins University Press, 1996.

KALYVAS, Andreas. Democracy and the Politics of the Extraordinary: Max Weber, Carl Schmitt, and Hannah Arendt. Cambridge: Cambridge University Press, 2009.

LEVINSON, Sanford. Constitutional Faith. 2. ed. Princeton: Princeton University Press, 2011.

MAUÉS, Antônio Gomes Moreira; SANTOS, Elídia Laurisdos. Estabilidade Constitucional e Acordos Constitucionais: os processos constituintes de Brasil (1987-1988) e Espanha (1977-1978). Revista Direito FGV, São Paulo, v. 4, n. 2, p. 349-388, 2008.

MICHELMAN, Frank I. Is the Constitution a Contract for Legitimacy. Review of Constitutional Studies, v. 8, 2003.

MICHILES, Carlos. Cidadão constituinte: A saga das emendas populares. [s.l.]: Paz e Terra, 1989.

OLIVEIRA, Dante De. Diretas Já: 15 Meses que Abalaram a Ditadura. Rio de Janeiro: Record, 2004.

PAIXÃO, Cristiano. Democracia e Constituição: um golpe desconstituinte? JOTA, Democracia e Sociedade, 05/12/2016. Available at: <https://www.jota.info/opiniao-e-analise/artigos/ democracia-e-constituicao-um-golpe-desconstituinte-12052016>.

PAIXÃO, Cristiano. Direito, política, autoritarismo e democracia no Brasil: da Revolução de 30 à promulgação da Constituição da República de 1988. Araucaria: Revista Iberoamericana de filosofía, política y humanidades, n. 26, p. 146-169, 2011.

PEREIRA, Thomaz. Antecipação de eleições gerais é constitucional? Sim, Folha de São Paulo, 04/09/2016. Available at: <http://www1.folha.uol.com.br/opiniao/2016/04/1759168-antecipacao-de-eleicoes-gerais-e-constitucional-sim.shtml>.

POST, Robert C. Fashioning the Legal Constitution: Culture, Courts, and Law. Harvard Law Review, v. 117, p. 4, 2003.

POST, Robert; SIEGEL, Reva B. Democratic Constitutionalism. In: SIEGEL, Reva B.; BALKIN, Jack M. (Orgs.). The Constitution in 2020. Nova York: Oxford University Press, 2009, p. 25-34.

SARAT, Austin; KEARNS, Thomas R. History, Memory, and the Law. [s.I.]: University of Michigan Press, 2009. 
SARMENTO, Daniel. 21 Anos da Constituição de 1988: a Assembleia Constituinte de 1987/1988 e a Experiência Constitucional Brasileira sob a Carta de 1988. Dados, v. 29, n. 2, 2009.

SIEGEL, Reva B. She the People: The Nineteenth Amendment, Sex Equality, Federalism, and the Family. Harvard Law Review, v. 115, n. 4, p. 947-1046, 2002.

TEMER, Michel. Revisão Constitucional? Constituinte?. Revista do Tribunal de Contas da União, v. 29, n. $75,1998$.

UNGER, Roberto Mangabeira. Social Theory: Its Situation and Its Task : a Critical Introduction to Politics, a Work in Constructive Social Theory. [s.I.]: Verso, 2004.

VIEIRA, Oscar Vilhena. Riscos da constituinte exclusiva. Folha de São Paulo, 03/21/2015. Available at: <http://m.folha.uol.com.br/colunas/oscarvilhenavieira/2015/03/1606153-riscos-da constituinte-exclusiva.shtml $>$.

WEBER, Max. Economy and Society: An Outline of Interpretive Sociology. [s.l.]: University of California Press, 1978. 